\title{
Corticotroph tumor progression after bilateral adrenalectomy (Nelson's syndrome): systematic review and expert consensus recommendations
}

\author{
Martin Reincke ${ }^{1, *}$, Adriana Albani 1,*, Guillaume Assie², Irina Bancos ${ }^{3}$, Thierry Brue ${ }^{4}$, Michael Buchfelder ${ }^{5}$, \\ Olivier Chabre ${ }^{6}$, Filippo Ceccato ${ }^{7}$, Andrea Daniele ${ }^{7}$, Mario Detomas ${ }^{8}$, Guido Di Dalmazi ${ }^{9}$, Atanaska Elenkova ${ }^{10}$, \\ James Findling ${ }^{11}$, Ashley B Grossman ${ }^{12}$, Celso E Gomez-Sanchez ${ }^{13}$, Anthony P Heaney ${ }^{14}$, Juergen Honegger ${ }^{15}$, \\ Niki Karavitaki@16,17,18, Andre Lacroix@19, Edward R Laws ${ }^{20}$, Marco Losa'1, Masanori Murakami1 ${ }^{122}$, \\ John Newell-Price ${ }^{23}$, Francesca Pecori Giraldi@24, Luis G Pérez-Rivas', Rosario Pivonello25, William E Rainey ${ }^{26}$, \\ Silviu Sbiera ${ }^{8}$, Jochen Schopohl', Constantine A Stratakis ${ }^{27}$, Marily Theodoropoulou', \\ Elisabeth F C van Rossum ${ }^{28}$, Elena Valassi ${ }^{29}$, Sabina Zacharieva ${ }^{10}$, German Rubinstein ${ }^{1, \dagger}$ and Katrin Ritzel ${ }^{1, \dagger}$
}

${ }^{1}$ Klinikum der Ludwig-Maximilians-Universität München, Medizinische Klinik und Poliklinik IV, Munich, Germany, ${ }^{2}$ Department of Endocrinology, Université de Paris, Institut Cochin, INSERM, CNRS, Center for Rare Adrenal Diseases, Hôpital Cochin, Paris, France, ${ }^{3}$ Division of Endocrinology, Mayo Clinic Minnesota, Diabetes, Metabolism, Nutrition, Rochester, Minnesota, USA, ${ }^{4}$ Aix-Marseille Université, Institut National de la Santé et de la Recherche Médicale (INSERM), U1251, Marseille Medical Genetics (MMG), Institut MarMaRa and Endocrinology Department, Conception Hospital, Assistance Publique-Hôpitaux de Marseille (APHM), Marseille, France, ${ }^{5}$ Universitätsklinikum Erlangen, Neurochirurgische Klinik, Erlangen, Germany, ${ }^{6} \mathrm{CHU}$ Grenoble-Alpes, Unit of Endocrinology, Pavillon des Ecrins, Grenoble, France, ${ }^{7}$ Department of Medicine, University of Padova, Padova, Veneto, Italy, ${ }^{8}$ Division of Endocrinology and Diabetology, Department of Internal Medicine, University of Würzburg, Wurzburg, Bayern, Germany, ${ }^{9}$ Department of Medical and Surgical Sciences, Endocrinology and Diabetes Prevention and Care Unit, University of Bologna, S. Orsola Policlinic, Bologna, Italy, ${ }^{10}$ Department of Endocrinology, Medical University Sofia, Sofia, Bulgaria, ${ }^{11}$ Division of Endocrinology and Molecular Medicine, Medical College of Wisconsin, Menomonee Falls, Wisconsin, USA, ${ }^{12}$ Oxford Centre for Diabetes, Endocrinology and Metabolism, University of Oxford, Centre for Endocrinology, Barts and the London School of Medicine, Queen Mary University of London, UK, ${ }^{13}$ Department of Pharmacology and Toxicology and Medicine, Endocrine Service, G.V. Montgomery VA Medical Center, University of Mississippi Medical Center, Jackson, Mississippi, USA, ${ }^{14}$ Division of Endocrinology, Medical Director, Pituitary \& Neuroendocrine Tumor Program, UCLA School of Medicine, Los Angeles, California, USA, ${ }^{15}$ Department of Neurosurgery, University of Tübingen, Tübingen, Germany, ${ }^{16}$ Institute of Metabolism and Systems Research, College of Medical and Dental Sciences, University of Birmingham, ${ }^{17}$ Centre for Endocrinology, Diabetes and Metabolism, Birmingham Health Partners, ${ }^{18}$ Department of Endocrinology, Queen Elizabeth Hospital, University Hospitals Birmingham NHS Foundation Trust, Birmingham, UK, ${ }^{19}$ Division of Endocrinology, Department of Medicine, Centre hospitalier de I'Université de Montréal (CHUM), Montréal, Québec, Canada, ${ }^{20}$ Pituitary/Neuroendocrine Center, Brigham and Women's Hospital, Harvard Medical School, Boston, Massachusetts, USA, ${ }^{21}$ Department of Neurosurgery, IRCCS San Raffaele Scientific Institute, Vita-Salute San Raffaele University, Milano, Italy, ${ }^{22}$ Department of Molecular Endocrinology and Metabolism, Graduate School of Medical and Dental Sciences, Tokyo Medical and Dental University, Tokyo, Japan, ${ }^{23}$ Dept of Oncology and Metabolism, The Medical School University of Sheffield, Sheffield, UK, ${ }^{24}$ Department of Clinical Sciences \& Community Health, University of Milan Neuroendocrinology Research Laboratory, Instituto Auxologico Italiano IRCCS, Milan, Italy, ${ }^{25}$ Dipartimento di Medicina Clinica e Chirurgia, Sezione di Endocrinologia, Università Federico II di Napoli, Naples, Italy, ${ }^{26}$ Departments of Molecular \& Integrative Physiology and Medicine, University of Michigan, Ann Arbor, Michigan, USA, ${ }^{27}$ Section on Genetics \& Endocrinology Eunice Kennedy Shriver National Insitute of Child Health \& Human Development (NICHD) National Institute of Health (NIH), NIH Clinical Research Center, Bethesda, Maryland, USA, ${ }^{28}$ Department of Internal Medicine, division of Endocrinology, Erasmus MC, University Medical Center Rotterdam, Rotterdam, The Netherlands, and ${ }^{29}$ IIB-Sant Pau and Department of Endocrinology/Medicine, Hospital Sant Pau, UAB, and Centro de Investigación Biomédica en Red de Enfermedades Raras (CIBER-ER, Unidad 747), ISCIII, Barcelona, Spain

*(M Reincke and A Albani contributed equally as joint first authors ) †(G Rubenstein adn K Ritzel contributed equally as joint last authors)

Correspondence should be addressed to M Reincke Email martin.reincke@med. uni-muenchen.de

\begin{abstract}
Background: Corticotroph tumor progression (CTP) leading to Nelson's syndrome (NS) is a severe and difficult-to-treat complication subsequent to bilateral adrenalectomy (BADX) for Cushing's disease. Its characteristics are not well described, and consensus recommendations for diagnosis and treatment are missing.
\end{abstract}

Published by Bioscientifica Ltd 
Methods: A systematic literature search was performed focusing on clinical studies and case series ( $\geq 5$ patients). Definition, cumulative incidence, treatment and long-term outcomes of CTP/NS after BADX were analyzed using descriptive statistics. The results were presented and discussed at an interdisciplinary consensus workshop attended by international pituitary experts in Munich on October 28, 2018.

Results: Data covered definition and cumulative incidence (34 studies, 1275 patients), surgical outcome (12 studies, 187 patients), outcome of radiation therapy (21 studies, 273 patients), and medical therapy (15 studies, 72 patients). Conclusions: We endorse the definition of CTP-BADX/NS as radiological progression or new detection of a pituitary tumor on thin-section MRI. We recommend surveillance by MRI after 3 months and every 12 months for the first 3 years after BADX. Subsequently, we suggest clinical evaluation every 12 months and MRI at increasing intervals every 2-4 years (depending on ACTH and clinical parameters). We recommend pituitary surgery as first-line therapy in patients with CTP-BADX/NS. Surgery should be performed before extrasellar expansion of the tumor to obtain complete and long-term remission. Conventional radiotherapy or stereotactic radiosurgery should be utilized as second-line treatment for remnant tumor tissue showing extrasellar extension

\section{Introduction}

Cushing's disease (CD) is caused by a pituitary corticotroph adenoma producing sustained levels of adrenocorticotropic hormone (ACTH), leading to excessive glucocorticoid secretion. The treatment of choice is transsphenoidal surgery (TSS) with selective removal of the adenoma tissue. Rates for persistence of CD or recurrence after initial remission were reported with a great variability depending on the ratio of micro-/macroadenoma, the experience of the surgeons and the definition for persistence and recurrence $(1,2)$. Based on meta-analyses the rates for persistence and recurrence after initial TSS ranged from 22 to $24 \%$ (persistence) $(3,4,5)$ and $10-12 \%$ (recurrence) (4), respectively. Studies with a longer follow-up showed higher recurrence rates. Although the highest risk for recurrent disease is observed in the first five years (6), it can occur as late as several decades after surgery and lifelong surveillance for recurrence is essential. Second-line treatments in persistent and recurrent $\mathrm{CD}$ include repeat transsphenoidal surgery, fractionated pituitary radiation and radiosurgery, medical therapy targeting ACTH and cortisol excess, and bilateral adrenalectomy (BADX). BADX is highly effective but leads to permanent adrenal insufficiency requiring life-long steroid replacement therapy with the risk of lifethreatening adrenal crisis. Therefore, BADX is generally considered the ultima ratio in $\mathrm{CD}$ treatment used when all other treatment options have failed. The use of BADX is highly variable between centers.

One of the possible complications occurring after $\mathrm{BADX}$ is the subsequent growth of the corticotroph tumor.
Although the exact mechanism behind corticotroph tumor progression remains to be elucidated, it is believed that disinhibition of the corticotroph tumor might be caused by reduced glucocorticoid feedback on tumor cells.

The surveillance, diagnosis and treatment of corticotroph tumors that progress (CTP), possibly leading to Nelson's syndrome (NS) is not standardized. To our knowledge, there has never been a consensus on diagnosis and treatment. Therefore, we performed a systematic review of the literature on the definition of CTP after BADX leading to NS, its cumulative incidence, treatment and outcome of CTP. The results were presented and discussed at an interdisciplinary workshop attended by international pituitary experts in Munich on October 28, 2018.

\section{Methods of literature search and consensus}

Objective The objective of the current analysis was to develop an expert consensus for the management of patients with CTP after BADX leading to NS.

Methods We performed a systematic literature search on MEDLINE using the search terms 'Nelson's syndrome' or 'Nelson syndrome' or 'bilateral adrenalectomy' and 'Cushing's disease'. We searched for systematic reviews, clinical studies and case series ( $\geq 5$ patients). The search was limited to human studies and English language. We 
identified 635 publications, of which 80 met the inclusion criteria and were deemed to be relevant. The studies covered cumulative incidence (34 studies, 1275 patients undergoing BADX and 328 diagnosed with NS), surgical outcome (12 studies, 187 patients), outcome of radiation therapy (21 studies, 273 patients), and outcome of medical therapy (15 studies, 72 patients).

Evidence We analyzed definition, key features, cumulative incidence, treatment and long-term outcomes of CTP/NS after BADX using descriptive statistics. The majority of the available data were of low quality (observational studies, unsystematic clinical experience, no randomized trials) and key outcome parameters could often not be defined due to the heterogeneity of the studies. For this reason, the evidence was not formally graded.Analog to the Grading of Recommendations, Assessment, Development, and Evaluation Group criteria (GRADE), we used 'recommend' for strong recommendations and 'suggest' for weak recommendations (7).

Consensus process We achieved consensus by collecting the best available evidence and conducting one group meeting on October 28, 2018 and exchanged multiple e-mail communications.

\section{History, terminology and key features}

In 1958 Don H Nelson published the first description of a progressive ACTH-producing pituitary tumor following BADX; a case of deep pigmentation after BADX had already been recognized by Dr Allan W. Spence at London's St Bartholomew's Hospital in 1957 (8). The syndrome, initially coined 'post-adrenalectomy syndrome', was characterized by hyperpigmentation, elevated ACTH and an expanding sellar mass (9). One year later in 1959, Robert M. Salassa reported the first series of 5 patients with a progressive corticotroph tumor after bilateral adrenalectomy (10). Over time, the terminology 'Nelson's syndrome' was more widely used than 'Nelson-Salassa syndrome' as indicated by the number of references in the scientific domain (Pubmed search: 598 hits vs 5 hits, April 2020).

In early studies, NS was often defined by the appearance of the clinical manifestations such as hyperpigmentation or a visual field defect. With advances in neuroimaging and the availability of CT and later MRI, clinical and laboratory indicators became less important for the diagnosis of NS. In 2007, the term 'corticotroph tumor progression (CTP)' was proposed by Assie et al. to amend or replace 'Nelson's syndrome' (11). This alternative terminology shifts the focus to the key feature of NS: An expanding pituitary corticotroph tumor as the primary clinical problem occurring subsequent to removal of both adrenal glands (BADX). However, NS is well established as medical eponym, and a change in medical terminology is difficult to achieve (12). Therefore, we suggest keeping NS as a supplement to CTP.

\section{Consensus recommendation 1}

We suggest amending the terminology from 'Nelson's syndrome' (NS) to 'Corticotroph Tumor Progression after bilateral adrenalectomy/Nelson's syndrome' (CTPBADX/NS).

\section{Definition and diagnosis of CTP-BADX /NS}

\section{Corticotroph tumor progression in pituitary imaging}

In early publications, skull radiographs were used for diagnosing sellar masses $(13,14,15,16,17,18,19,20$, $21,22,23,24,25)$. The assumption of pituitary tumor progression was based on findings of sellar enlargement, and distortion or thinning of the dorsum sellae. Also, clinical signs of tumor infiltration such as loss of vision were used for diagnosis. Since the 1980s pituitary tumors have been diagnosed with tomographic techniques (CT and later MRI $(11,26,27,28,29,30,31,32,33,34,35,36$, $37,38,39,40,41,42))$. Although CT allowed more accurate description and earlier identification of pituitary tumor progression, diagnostic criteria were still heterogeneous. Some studies defined CTP-BADX/NS by the presence of a pituitary tumor on a post-adrenalectomy scan, while other studies requested progression or new occurrence. There were also inconsistencies in the interpretation of tumor size as a diagnostic marker. In the majority of studies, the presence of a microadenoma was sufficient to diagnose CTP-BADX/ NS, while some publications required macroadenomas $(\geq 10 \mathrm{~mm})$ or the need for clinical intervention $(29,31$, 35, 39). From 2007 onwards, the definition of CTP-BADX/ NS became more consistent, requiring significant tumor 
progression on neuroimaging $(11,38,41,42)$. Serial MRI with assessment of diameter, volume and potential parasellar extension has become the gold standard for the detection and evaluation of pituitary masses.

Precise volumetric measurement of pituitary tumors is often hampered by their irregular morphology, particularly after surgical resection, and standardized methods for imaging interpretation remain to be validated.

Summary: Radiological evidence of progression or a new occurrence of a pituitary tumor after BADX on MRI have become the basis for the diagnosis of CTP-BADX/NS in current clinical practice.

\section{Hyperpigmentation}

Hyperpigmentation of the skin and mucous membranes after bilateral adrenalectomy is a common clinical feature caused by binding of ACTH and other POMC splicing products to the melanocortin-1 receptor (MC1R). Objective evaluation and quantification of this criterion is difficult because an individual's skin color is influenced by many factors, such as ethnicity or sun exposure. The presence of MC1R genetic variants might also affect the degree of skin darkening, as previously reported for primary adrenal insufficiency (43). However, hyperpigmentation has served as a diagnostic criterion in several studies and has been documented in many publications. In earlier studies, before tomographic imaging was widely available, hyperpigmentation after BADX was more prevalent than expanding pituitary tumors $(13,14,15,16,17,18,19$, $20,21,22,23,24,26,28,30,32,35,36)$. Interestingly, a recent study showed that a considerable number of patients with tumor progression on MRI had no obvious hyperpigmentation, indicating that tumor progression on MRI imaging might precede hyperpigmentation in some cases (42).

Although hyperpigmentation seems a less reliable diagnostic criterion than MRI documented tumor progression, it has clinical significance as a potential indicator of ACTH increase after BADX. In addition, hyperpigmentation can impact negatively on quality of life, especially at a younger age. The phenotypic changes associated with skin darkening are relevant for self-image and social interactions.

Summary: The new development or intensification of hyperpigmentation is an indicator of potential CTP and should lead to further diagnostic steps. A possible psychosocial impact on the affected patients, especially in children and adolescents, should also be carefully monitored in clinical practice.

\section{ACTH elevation}

ACTH as a tumor marker for CTP-BADX/NS has been measured and evaluated in most studies. Systematic comparisons between reports are difficult and limited by the use of different analytical methods (RIA vs automated immunoassays), different units (pmol/L vs $\mathrm{pg} / \mathrm{mL}$ ) and different blood sampling protocols (e.g. in the morning before or in the morning following hydrocortisone substitution). The latter aspect needs special consideration since it has been shown that ACTH concentrations are profoundly influenced by the interval to the last glucocorticoid replacement dose (GC) (44). Another factor is that aggressive pituitary tumors after BADX might secrete high molecular weight ACTH, which cannot be detected by routine ACTH assays, resembling some 'silent' corticotroph adenomas (45). In general, ACTH measurement is challenging with complex preanalytical requirements. As a consequence, there is some controversy about the reliability of automated immunoassays $(46,47)$. Thus, caution is required not only in the interpretation of available research data but also in the use of plasma ACTH cut-offs as the basis for clinical decision making. Since spontaneous fluctuation of plasma ACTH can occur, monitoring of the ACTH level over time might be valuable to detect a progressive rise.

Most studies analyzed in the context of the present work showed increasing ACTH levels in patients following BADX. Similar to hyperpigmentation, ACTH elevation was more prevalent than radiologically documented pituitary tumor progression, especially in earlier studies with less sophisticated imaging techniques $(26,28,39)$. In direct comparison, average ACTH values were higher in patients with CTP-BADX/NS compared to patients without CTPBADX/NS (956 vs $276 \mathrm{pg} / \mathrm{mL}$ (211 vs 61 pmol/L) (11, 34, $40,48)$. The threshold of ACTH that could discriminate between patients with and without CTP-BADX/NS in different studies ranged from 200 to $700 \mathrm{pg} / \mathrm{mL}$, with a mean of $396 \mathrm{pg} / \mathrm{mL}$ (44 to $154 \mathrm{pmol} / \mathrm{L}$, mean $87 \mathrm{pmol} / \mathrm{L}$ ) $(11,21,23,28,32,34,36,38)$. Summary: A consistent ACTH threshold indicating CTP-BADX/NS, as well as the timing of sampling remains to be established.

\section{Conclusions}

In earlier descriptions, CTP-BADX/NS was defined by the typical triad (hyperpigmentation, elevated ACTH, and progressive pituitary adenoma). While the expanding pituitary tumor is the primary clinical problem, hyperpigmentation and elevated plasma 
ACTH are concomitant features. Available data suggest that hyperpigmentation and elevated ACTH are neither specific nor sensitive enough to be classified as primary diagnostic criteria for CTP-BADX/NS. Nonetheless, hyperpigmentation and ACTH excess are important clinical and biochemical evidence after BADX for CD, and possible indicators for CTP-BADX/NS. Longitudinal changes indicating an increase in ACTH seem to be more indicative for CTP-BADX/NS than an individual ACTH value after BADX. To standardize, sampling for ACTH measurement is recommended at 08:00 a.m. prior to the morning dose of GC (49).

\section{Consensus recommendation 2}

As a primary criterion for the definition and diagnosis of CTP-BADX/NS, we recommend radiological evidence of corticotroph tumor progression or the new detection of a radiologically visible pituitary tumor after BADX. We further suggest hyperpigmentation and a progressive rise in plasma ACTH after BADX (assessed by immunoassay, at 08:00 $\mathrm{h}$ prior to the morning dose of $\mathrm{GC}$ ) as nonmandatory secondary criteria of CTP-BADX/NS.

\section{Cumulative incidence of CTP-BADX/NS}

Cumulative incidence of Nelson's syndrome in adults

Studies were excluded if the definition of CTP-BADX/ NS was not given in the publication. The remaining 34 studies were analyzed on the basis of imaging modality (radiography vs tomography).

In the pre-tomography area, CTP-BADX/NS was mainly diagnosed by skull radiography. From 1971 until 1985, 10 publications investigated the cumulative incidence of CTP-BADX/NS in adults diagnosed with Cushing's disease who underwent BADX $(13,14,15,17$, $19,20,21,22,23,24)$. CTP-BADX/NS occurred in $20 \%$ (0-46\%) of the patients.

In studies published from 1990 onwards, CT and MRI have been mainly used for pituitary imaging. The mean cumulative incidence of CTP-BADX/NS in these studies was $29 \%$, ranging from 8 to $53 \%$. The large variability was due to the fact that the diagnostic criteria for CTP-BAD/ NS were still heterogeneous $(11,26,27,28,29,30,31,32$, $33,34,35,36,37,38,39,40,41,42,48)$. As an example, the lowest cumulative incidence of CTP-BADX/NS (8\%) was observed in a study where CTP-BADX/NS was defined by the need for intervention for a pituitary tumor (39). A more consistent definition was introduced from 2007 onwards, with CTP-BADX/NS mainly defined by the new occurrence or significant corticotroph tumor progression on CT or MRI scans. The mean prevalence of CTP-BADX/ NS in these studies was 43\% (28-53\%) $(11,38,41,42)$.

\section{Predictive factors}

Some publications were able to establish factors associated with an increased risk of developing CTP-BADX/NS (Supplementary Table 2, see section on supplementary materials given at the end of this article). High ACTH plasma concentrations in the first year after BADX seemed to be predictive of CTP-BADX/NS $(11,21,28$, $34,48)$. Patients with an obvious adenoma $(33,34)$ or larger tumor size before BADX (6 mm vs $1 \mathrm{~mm}(42)$ ) had an increased cumulative incidence of CTP-BADX/ NS after BADX. Additionally, young age at BADX was positively associated with the appearance of CTP-BADX/ NS. Patients younger than 35 years at BADX seem to have a particularly increased risk $(22,29,37,42)$. Cushing's disease has a female preponderance and more female than male patients undergo BADX. In 11 studies, specification of gender allowed calculation of the gender-related risk of CTP-BADX/NS (15, 16, 17, 21, 22, 29, 34, 36, 38, 42, 48). The majority of BADX patients were female (394 of 500). The mean proportion of female patients who developed CTP-BADX/NS was equivalent to the proportion of female patients in the group that was not diagnosed with CTP-BADX/NS (77.7\% vs 78.4\%). While CD has higher preponderance in females, the cumulative incidence of CTP-BADX/NS is not sexually discordant. The effect of pregnancy on CTP-BADX/NS has been investigated in 11 women who became pregnant at a median time interval of 3.5 years after BADX by serial pituitary MRI bevor, during and after pregnancy. Interestingly, pregnancy did not accelerate corticotroph tumor progression (50).

The effect of radio therapy before BADX and prophylactic radio therapy on the risk of CTP-BADX has not been clarified yet and will be discussed later.

Patients with aggressive adenomas, not controlled by surgery and radiation, have a higher probability to undergo BADX for persistent or recurrent disease. These resistant adenomas might either be particularly sensitive to the loss of feedback inhibition after BADX or exhibit a distinct intrinsic aggressiveness. So far, histopathological examination of pituitary tumors from transsphenoidal surgery prior to BADX could not identify a subtype that predicts the development of CTP-BADX/NS. Staining patterns, as well as mitotic rates and Ki-67 immunopositive nuclei from previous TSS, were not different between 
patients developing CTP-BADX/NS and patients without CTP-BADX/NS $(11,42)$.

However, CTP-BADX/NS histology showed low p27 labeling indices and higher proliferation rates than corticotroph pituitary tumors from patients not undergoing BADX $(51,52,53)$. Therefore, the role of histopathology and new molecular markers for the development of CTPBADX/NS remains to be established by further research (54). Recently, somatic driver mutations in the ubiquitinspecific protease 8 (USP8) gene have been implicated in the pathogenesis of Cushing's disease (55). These mutations appear to have a similar prevalence in CTP-BADX/NS, excluding the possibility that they drive the corticotroph tumor progression that leads to CTP-BADX/NS (56). Overall, progressing corticotroph tumors seem to be a heterogeneous group in terms of molecular characteristics and clinical behavior. Molecular pathways involved in growth regulation need to be further elucidated.

\section{Cumulative incidence of Nelson's syndrome in childhood}

Three publications investigated the cumulative incidence of CTP-BADX/NS in childhood, all dating back to the pretomography era. The mean cumulative incidence of CTPBADX/NS was considerably higher compared to results in adult patients $(45 \%, 25-67 \%)(16,18,25)$. The lack of more recent data is most likely due to the rare occurrence of $\mathrm{CD}$ in childhood, and the restrictive use of BADX after evolution of transsphenoidal microsurgery (57).

\section{Time interval between BADX and diagnosis of CTP-BADX/NS}

The mean time interval between BADX and diagnosis of CTP-BADX/NS was 5.3 years $(9,10,11,13,14,15,16,17$, $18,19,20,21,22,56)$. However, the occurrence of СТРBADX/NS has been reported from as little as 2 months up to 27 years after $\operatorname{BADX}(18,38)$. In more recent studies, using CT or MRI imaging and more consistent criteria for CTP-BADX/NS, the time between BADX and CTP-BADX/ NS was 2.5 years $(0.2-8)(11,38,41,42)$. A previous study reported a median growth rate of $3 \mathrm{~mm} /$ year $(0.5-21 \mathrm{~mm})$ (38): from these data, surveillance by tomographic imaging every 12 months for the first 3 years seems reasonable.

\section{Conclusions}

The large variability in the cumulative incidence of CTPBADX/NS and in the time of development after BADX may be mainly due to the lack of consistent diagnostic criteria. This emphasizes the need for a clear and standardized definition. CT and especially MRI imaging have a higher sensitivity than clinical and radiographic signs for the diagnosis of CTP-BADX/NS. The high CTPBADX/NS cumulative incidence of around $40 \%$ in more recent publications probably reflects the true incidence of corticotroph tumor progression detected at an early stage. Since MRI allows diagnosis of tumor progression in the subclinical state, a diagnosis of CTP-BADX/NS does not necessarily need treatment but requires close follow-up.

\section{Consensus recommendation 3.1}

We recommend close surveillance in patients with any of the following conditions: (1) high plasma ACTH after BADX or an increasing ACTH level; (2) visible corticotroph tumor prior to BADX; (3) patients younger than 35 years of age. The role of histopathological and molecular markers for the prediction of CTP-BADX/NS remains to be evaluated.

\section{Consensus recommendation 3.2}

We recommend surveillance by MRI imaging (1-2 mm slice thickness) after 3 months and every 12 months for the first 3 years after BADX. CT should be only suggested as a method of second choice in patients with contraindications for MRI. We suggest clinical surveillance every 12 months and MRI imaging at increasing intervals every 2-4 years (depending on ACTH and clinical parameter) afterwards. In high-risk patients, closer surveillance might be required.

\section{Outcome of pituitary surgery in CTP-BADX/NS}

\section{Surgical series of patients with CTP-BADX/NS}

Successful surgical treatment of CTP-BADX/NS remains a great challenge. Because of the rarity of the syndrome, only 12 relevant clinical studies on outcome of neurosurgery have been reported since 1976 (187 patients).

\section{Total hypophysectomy vs selective adenomectomy}

Most experts agree that neurosurgical resection of the pituitary tumor should be the first-line therapy in patients with CTP-BADX/NS. In the early years, total 
hypophysectomy was considered the preferred technique because of the potentially aggressive behavior of these tumors, a tendency to recurrence, and disappointing results of selective adenomectomy $(58,59)$. For example, in 1980, a study reported tumor control in 4 of 19 tumors by selective adenomectomy, whereas 4 patients died as direct consequence of the tumor (59). Nevertheless, with advances in microsurgery, the outcomes of pituitary surgery have improved, leading to the recommendation to use selective adenomectomy as the preferred technique (60).

\section{Transsphenoidal vs transcranial approach}

The transsphenoidal approach is a relatively effective and safe procedure, and it is the preferred technique when feasible $(37,60,61,62,63,64,65)$. However, the outcomes of neurosurgery in CTP-BADX/NS are worse in comparison to those achieved in other types of pituitary tumors. Kasperlik-Zaluska et al. divided CTP-BADX/NS into three stages: stage I, pituitary microadenoma without any signs of invasion; stage II, pituitary macroadenoma without any invasion; stage III pituitary macroadenoma with extrasellar/parasellar invasion (37). In their series of 30 patients undergoing surgery, the transsphenoidal approach appeared to be the method of choice for stages I and II. They recommended a transcranial intervention, sometimes combined with radiotherapy, in patients with tumors having a large extrasellar invasion. In these cases, combined therapy may be the only way to attain partial remission, which was defined by the authors as a distinct improvement in the clinical course of NS, with reduced size of the pituitary tumor and decreased - but still exceeding the upper limit of normal - plasma ACTH levels. Similarly, Zielinski et al., recommend the transsphenoidal approach in the pre-invasive phase and the transcranial approach in invasive tumors (65). Our consensus panel emphasized transsphenoidal surgery as the preferred technique in the majority of the cases, depending mostly on tumor localization and growth direction, similar to the approach in other subtypes of pituitary tumors.

The interval between BADX and neurosurgery ranged from 7 months to 18 years, indicating the unpredictable behavior of these tumors $(59,60)$. Significant progression of the corticotroph tumor can occur quickly, leading to an extrasellar extension (62). In large tumors pituitary apoplexy can occur, leading to neurological complications and even death $(37,60)$. A significant proportion of CTP showed aggressive growth behavior (13-21\%) $(37,59)$. Cases of anaplastic pituitary tumors have been reported $(37,66)$.

\section{Remission rates of surgery}

The most relevant studies reporting on the outcome of pituitary surgery in patients with CTP-BADX/NS are summarized in Supplementary Table 3. Remission rates after surgery ranged between 17 and 80\%: Outcome was mainly influenced by tumor volume and the degree of extrasellar extension. However, different criteria of remission have been used over the years. All authors agree that a more favorable prognosis with fewer complications after neurosurgery occurs in microadenomas and intrasellar macroadenomas, whereas large tumors with cavernous sinus invasion have a low chance of complete tumor excision (62). Intrasellar tumors have been reported to be in remission after neurosurgery in $70-80 \%$ of the cases, leading also to a more pronounced reduction of plasma ACTH levels $(60,66,67)$. The best surgical outcome in those patients treated at an early stage was documented in a large cohort of 30 patients with CTP-BADX/NS (37). Wilson and coworkers reported that none of the 10 patients with macroadenomas had normalized plasma ACTH levels after neurosurgery (59). In Zielinski's report, all cases that did not achieve remission after surgery were grade IV tumors (according to the Knosp scale) with infiltration of the cavernous sinus $(65,68)$. The extent of parasellar growth, as measured by the Knosp scale, was established as the main factor influencing the effectiveness of surgical treatment. Accordingly, remission was documented only in patients with small tumors and limited intrasellar extension. All these data support early surgery, preferably before supra- or parasellar extension occurs.

Considering that tumors in patients with CTP-BADX/ NS in historic series were mainly macroadenomas, visual field alterations secondary to optic chiasm compression occurred in $10-51 \%$ of cases $(58,59,60,61,62,63,65$, $66,67)$. Neurosurgery can achieve improvement in visual defects through decompression of the optic chiasm (58, $61,63,65)$. Cranial nerve palsies such as cranial nerve III paresis, are also reported pre-operatively in this population with a frequency of $23 \%$ (61). Its complete or partial resolution after neurosurgery is documented $(58,61)$.

\section{Long-term follow-up after surgery}

A limited number of studies have reported longterm follow-up after neurosurgery in CTP-BADX/NS (Supplementary Table 3). Xing and coworkers reported a mean follow-up of 3.6 years after neurosurgery in 23 patients with CTP-BADX/NS, with recurrence in $13 \%$ (63). Wislawski et al. documented the follow-up of 10 
patients, ranging from 6 months to 10 years, and observed recurrences in 2 patients (20\%), within 1 and 1.5 years, respectively (66). In the series of Kelly et al., long-term follow-up at a median of 17 years demonstrated normal pigmentation, plasma ACTH levels less than $200 \mathrm{pg} /$ $\mathrm{mL}(44 \mathrm{pmol} / \mathrm{L})$ and no visible pituitary tumor in 6 of 13 patients with CTP-BADX/NS (61). In a small cohort of six patients with intrasellar CTP-BADX/NS, only one had a recurrent ACTH elevation after 10 years follow-up, without evidence of tumor regrowth (60).

Recently, a large retrospective study assessed the outcome of patients with CTP-BADX/NS followed for a median of 13 years (69). Of 68 patients with CTP-BADX/ NS, 28 underwent pituitary surgery $(n=10$ surgery only; $n=18$ surgery plus radiotherapy), 22 radiotherapy alone, 2 were treated with pasireotide and 16 were observed without treatment. The 10-year tumor progression-free survival was higher in patients treated with pituitary surgery, either alone or in combination with radiotherapy, attaining a figure of $\sim 80 \%$ (69).

\section{Side effects of surgery}

Pituitary surgery in CTP-BADX/NS is associated more frequently with side effects than primary TSS, since patients are more often subjected to repeated interventions. Still, cerebrospinal fluid leak (CSF) and meningitis have been rarely reported as complications $(61,65)$. Hypopituitarism or the onset of new pituitary deficits is reported in 5-30\% of cases $(58,60,62,64,65)$. Exceptionally, Kelly et al. described hypopituitarism after surgery in a higher percentage (69\%) (61). However, a total hypophysectomy was performed in all 13 patients. Permanent diabetes insipidus has been reported in $18-38 \%$ of cases $(61,62$, $65)$. Mortality has been described as direct consequence of tumor progression, pituitary apoplexy or metastasis rather than a surgical complication $(37,59,62,65,69)$. Death shortly after pituitary surgery has been reported in few patients $(37,69)$.

\section{Conclusions}

The limitations of this analysis are the variable criteria used to define remission of CTP-BADX/NS and the lack of detailed information regarding imaging, biochemical values and other therapies used before and/or after neurosurgery in some studies. On the other hand, neurosurgical techniques have improved considerably over the last decades through the evolution of transsphenoidal approaches and modern microinstrumentation. The published data have demonstrated that transsphenoidal surgery is the first choice of treatment for CTP-BADX/NS and can be performed safely in the majority of patients.

\section{Consensus Recommendation 4.1}

We recommend pituitary surgery as first-line therapy in patients with CTP-BADX/NS. Surgery should be performed before extrasellar expansion of the tumor occurs in order to obtain complete and long-term remission.

\section{Consensus Recommendation 4.2}

We recommend selective removal of the pituitary adenoma by a transsphenoidal approach in micro- and macroadenomas, when technically feasible.

Transcranial surgery is to be discussed exclusively for supra-diaphragmatic locations, when extended transsphenoidal approach is not achievable or not perceived as the optimal benefit/risk ratio (low evidence, weak recommendation).

\section{Effect of prophylactic pituitary radiotherapy to prevent CTP-BADX/NS}

The available literature on this subject is sparse, many studies are based on data sources from previous decades and all data are retrospective. Several studies have evaluated the effect of radiotherapy on the risk of developing CTP-BADX/NS. However, most studies have not clearly distinguished between prophylactic radiotherapy or therapeutic radiation of a corticotroph tumor prior to BADX. Additionally, the absence of a control group in several studies and the low number of patients receiving radiation limits interpretation.

Five of the studies (total $n=149$ patients with BADX of which 91 patients received radiation) reported a potential beneficial effect of radiation in reducing the cumulative incidence of CTP-BADX/NS $(13,21,32,38$, 70). Conventional radiotherapy was used in four studies (30-50 Gy, fractionated). Two of these studies had control groups, showing a reduction in CTP-BADX/NS from 50 to $25 \%$ and 50 to $0 \%$ in treated patients $(32,38$ ). Radiosurgery was used in the most recent analysis with a remarkably low cumulative incidence of CTP-BADX/NS (5\%) (70) after prophylactic gamma knife radiation.

In contrast to these publications, two studies ( $n=208$ patients with BADX, of which 45 patients received radiation) could not confirm a risk reduction 
for CTP-BADX/NS by radiotherapy $(15,42)$. Another investigation found a high cumulative incidence of CTPBADX/NS despite low dose pituitary radiation in a small group of patients (26). Together, the data are not sufficient for a general recommendation of prophylactic radiation, and the question of whether radiotherapy can prevent CTP-BADX/NS remains unanswered. In particular, the therapeutic effect of radiosurgery to prevent corticotroph tumor progression needs to be examined by further studies.

\section{Consensus recommendation 5.1}

We suggest against the routine use of prophylactic pituitary radiation (fractionated or radiosurgery) to prevent corticotroph tumor progression. In cases of invasive macroadenomas with incomplete resection concomitant radiotherapy should be discussed by an interdisciplinary team before BADX.

\section{Radiation therapy of CTP-BADX/NS}

Radiation therapy can be used as a primary treatment option in pituitary adenomas, or secondary when surgical failure is evident. In general, the outcome of radiation therapy for CTP-BADX/NS is less favorable compared to other forms of pituitary adenomas. Radiation therapy is mainly divided into conventional radiotherapy (CRT) and stereotactic radiosurgery (SRS). Supplementary Table 4 summarizes the outcomes of radiation therapy and its complications and side effects in patients with CTPBADX/NS. None of these studies reported rates for peri and post-procedural mortality.

\section{Conventional radiotherapy (CRT)}

CRT is based on an external photon source to radiate the targeted volume in 20-30 sessions and was used mainly in earlier years for the treatment of CTP-BADX/NS, although in total only 6 studies (1980-2019) with 58 patients have reported on its outcome $(19,62,69,71,72,73)$. Moreover, most of the studies focused on clinical and biochemical outcomes and lack data on radiological outcomes and possible side effects of CRT. Comparison to more recent studies is difficult, as often radiation of the whole sellar region was performed and therefore radiotherapy-induced hypopituitarism was common. In addition, earlier studies used different ACTH assays, and imaging with MRI was not available. Howlett et al. studied 15 patients with CTPBADX/NS treated with CRT (72). In 7 of them, CT scans were available demonstrating an empty sella after CRT in all $(7 / 7,100 \%)$. Kemink et al. reported tumor control in five of six patients (83\%) (62). ACTH normalization was reported in $50-60 \%$ of patients $(62,71)$. Two studies with 6 and 15 patients reported on new-onset hypopituitarism $(5 / 6,83 \%$; and 2/15, 13\%) $(62,72)$. As reported above, the largest study on the long-term outcome was recently published by Fountas et al., reporting retrospectively on 22 patients treated from 1969 to 2018 in 13 UK pituitary centers by 'radiotherapy' (19 with CRT, 2 with gamma knife surgery, 1 with cyber-knife surgery) (69). At 10-year follow-up, $52 \%$ of these patients showed tumor progression-free survival compared to $81 \%$ of patients treated by pituitary surgery together with radiotherapy and $80 \%$ of subjects treated by surgery alone. However, no further information on radiotherapy (target volume, used dose) and imaging technique nor on side effects was given.

\section{Stereotactic radiosurgery}

Stereotactic radiosurgery (SRS) uses a very high dose of radiation (considered lethal to cells) applied from different angles (3D) to a precisely defined target volume. Its rationale is that by concentrating radiation on the biological target, more normal surrounding tissue can be preserved. It is usually applied in a single-session, but is sometimes split up into five sessions. For SRS different technologies, sources of radiation and computer systems are used, but they all fulfil the aforementioned characteristics: gamma-knife surgery (GKS) is the most frequently used technique, using gamma rays from a cobalt-60 source. Radiosurgery from linear accelerator systems (LINAC) uses accelerated electrons colliding with a target and therefore generating photons as the radiation source. Finally, proton-based SRS uses accelerated protons with favorable physical characteristics, but the technology is expensive and not widely available. As the movement of the patient must be restricted, the patient's head gets fixed with either an invasive metal frame (in GKS) or a non-invasive mask (in LINAC).

Our systematic literature search identified 11 studies with outcome data on 179 patients (GKS: 7 studies with 150 patients $(74,75,76,77,78,79,80)$; proton-based SRS: 2 studies with 15 patients $(81,82)$; LINAC: 2 studies with 14 patients $(83,84)$.

Different definitions of outcome were applied, most of them focused on biochemical and radiological remission, as defined by a decline or normalization of ACTH and stable or decreasing volume of the adenoma. The main therapeutic aim was tumor growth control. Information on pre- and post-treatment status was not reported in all 
studies, and interpretation of these results has to be handled with caution, because a high percentage of patients treated with radiosurgery was previously treated with multiple operations and CRT for CTP-BADX/NS. Therefore, the isolated effect of radiosurgery might be overestimated.

\section{Gamma knife surgery (GKS) efficacy}

The majority of the studies reported excellent tumor growth control rates, ranging from 82 to $100 \%$. Since the studies had a mean follow-up of $>50$ months, and some even 85-144 months $(77,78)$, this indicates good longterm tumor control rates. In parallel, ACTH stabilization or an ACTH decrease was documented in $66-100 \%$ of the patients. The target volume was in the range of 1-2 $\mathrm{mL}$. Post-radiation tumor volume shrinkage by 33 and $32 \%$ was documented in two studies $(77,79)$. In patients who achieved ACTH normalization, time from GKS to normalization was 115 and 162 months in two studies $(77,78)$. A shorter interval between transsphenoidal surgery and GKS was associated with a better endocrine remission (80).

\section{GKS side effects}

Adverse effects were reported in six of seven studies. The most common adverse effect was new-onset hypopituitarism in $7-40 \%$ of patients (22\% in the largest series with 27 patients) (80). In some patients, the antitumor effect of GKS has led to the improvement of pituitary function and tapering of replacement therapy (79). Visual field deficits and cranial nerves palsies (CNP; transitory and permanent) were reported in 19 and $14 \%$, respectively $(77,78)$. It has to be noted, however, that many of the patients had received CRT before GKS, potentially increasing radiation-induced neuropathy. A single study reported that $10 \%$ of the patients had seizures (80). Additional radiation side effects, such as apoplexy and asymptomatic temporal lobe radiation necrosis, occurred in a small number of patients $(74,77)$. One case of glioblastoma multiforme occurred 15 years after GKS in a brain area exposed to no more than $1 \mathrm{~Gy}$ which lead the authors to the conclusion that this event was probably not related to the procedure (79).

\section{Proton-based SRS and SRS from LINAC}

Proton-based radiation has been suggested to have advantages over other forms of radiation as an even more precise and normal tissue sparing radiation might be possible. This so-called Bragg-peak effect allows protons to deposit almost all their energy in the targeted volume. So far, just two studies from 2008 and 2014 reported on 11 patients treated with proton-based SRS $(81,82)$. Stabilization of tumor growth was reported in both studies as $100 \%$, ACTH normalization in 75 and $100 \%$ : $52 \%$ of patients developed new hypopituitarism (81).

Two studies including 14 patients reported the outcome of LINAC radiosurgery $(83,84)$. Tumor control was achieved in 60 and $88 \%(83,84)$ and new hypopituitarism developed in $20 \%$ (83).

\section{Other forms of radiation}

Early studies $(1976,1977)$ reported outcomes in 28 patients treated by radiation with heavy particles $(910 \mathrm{MeV}$ alpha), leading to improvement of hyperpigmentation and decline of ACTH $(85,86)$; one study from 1976 used the implantation of Yttrium-90 and Gold-198 seeds into the pituitary, by which also improvement and an ACTH decline could be achieved (87).

\section{Conclusions}

Radiation therapy is commonly used in CTP-BADX/NS. In earlier years, CRT was widely used, with poorly documented outcome data. More recently, SRS with GKS has been used, leading to high tumor growth control rates of $>90 \%$. However, outcome data and side-effect rates of GKS have to be treated with caution, as most patients received CRT prior to GKS, the studies were retrospective, and essential data are often missing. Another major caveat is that recent technical advances in conventional, as well as stereotactic radiotherapy, limit the transferability of earlier outcome data to modern radiotherapy. In summary, although of low quality, these data support the concept that radiation therapy can be safely used for CTP-BADX/NS. In general, small tumor volumes are more suitable for SRS, whereas larger tumors may be more suitable for fractionated CRT.

\section{Recommendation 5.2}

We recommend radiation therapy for CTP-BADX/NS in patients with tumors not safely accessible by surgery or when complete tumor resection is not possible by surgery. An interdisciplinary tumor board should govern the indication for treatment, the choice of treatment and radiation technique considering clinical, radiological and pathological characteristics. 


\section{Outcome of medical treatment in CTP-BADX/NS}

Medical therapy in CTP-BADX/NS has been reported in a limited number of studies. Early studies focused on plasma ACTH levels as the outcome indicator, since CTP could not be followed-up because of a lack of accurate imaging techniques (CT and MRI).

\section{Medical therapy with a focus on plasma ACTH}

A few studies have investigated the effect of medical therapy on plasma ACTH as a surrogate marker of tumor growth. No effect was reported for either MSH releaseinhibiting factor (MIF) or rosiglitazone $(88,89,90$, 91). Reports on the efficacy of cyproheptadine, sodium valproate and dopamine agonists (bromocriptine and cabergoline) were heterogeneous. Whereas Krieger et al. reported an effect in three of four patients with CTPBADX/NS treated with cyproheptadine $24 \mathrm{mg} /$ day orally for 3-5 months, Cassar et al. observed no effect on ACTH levels in three patients receiving cyproheptadine $24 \mathrm{mg} /$ per day orally for 6 weeks and $40 \mathrm{mg} /$ day for 7 weeks $(92,93)$. Similarly, a single dose of $5 \mathrm{mg}$ bromocriptine in nine patients led to lowering of ACTH in one case, whereas a single dose of $2.5 \mathrm{mg}$ bromocriptine caused a significant decrease in plasma ACTH levels in six patients according to Mercado-Asis $(94,95)$. A few single case reports showed improvement of ACTH values and control of tumor growth with cabergoline, but larger studies are lacking (96). Sodium valproate $1200 \mathrm{mg}$ per day for 3 days resulted in lowered ACTH levels in three patients with CTP-BADX/NS (97). However, long-term therapy of six patients with sodium valproate $600 \mathrm{mg}$ per day for one year showed no significant effect on ACTH levels (98). In summary, these early studies do not provide evidence for consistent pharmacological effect of any of the investigated medications.

\section{Medical therapy focusing on tumor growth}

The alkylating chemotherapeutic agent temozolomide has been used with limited efficacy. One patient with invasive CTP-BADX/NS received temozolomide $200 \mathrm{mg} /$ $\mathrm{m}^{2} /$ day orally for 5 days of a 28-day cycle, leading to tumor shrinkage, improvement of headaches and lowering of ACTH levels after four cycles of treatment (99). Another case report of a patient with an invasive corticotroph tumor receiving temozolomide $150 \mathrm{mg} / \mathrm{m}^{2} /$ day for 5 days every 28 days for nine cycles resulted in marked clinical, biochemical, and radiological improvement. After stopping temozolomide tumor progression was observed after a 6-month period of remission (100). Furthermore, there was a single case of stable disease (101) and a report of a lack of response in a patient despite absent MGMT expression $(52,102)$ receiving temozolomide for CTPBADX/NS.

First-generation somatostatin analogus, acting on subtype-2 somatostatin receptors (SST2) were studied in a few patients: $100 \mu \mathrm{g}$ octreotide s.c. lowered ACTH levels and decreased tumor size in a patient with Nelson's syndrome (103); one patient received octreotide 300 $\mu \mathrm{g} /$ day for a maximum of 2 years leading to lowered ACTH levels and tumor shrinkage (104); in another patient receiving the same regiment, visual field defects normalized (105). The somatostatin analog pasireotide is a second-generation somatostatin receptor multi-ligand mainly acting on subtype 2 and 5 receptors (SST2, SST5). The effects of pasireotide on corticotroph tumor growth are discussed controversially (106). A recently published study reported dose and time-dependent reduction of tumor volume with pasireotide in patients with CD (107). Daniel et al. studied in an open-labeled multicenter longitudinal trial the effect of pasireotide in CTP-BADX/ NS (49). Seven patients with s.c. treatment demonstrated a significant reduction in morning plasma ACTH of around $50 \%$. This effect was maintained in five patients receiving long-acting pasireotide. An acute response to a test dose predicted outcome to long-term treatment in four of five patients. No significant change in tumor volumes was observed $(1.4 \pm 0.9$ vs $1.3 \pm 1.0, P=0.86)$. Four patients withdrew during the study. Hyperglycemia occurred in six patients. Besides lowering plasma ACTH levels, pasireotide had no major effects on tumor growth in patients with CTP-BADX/NS. Based on their study in 60 corticotroph adenomas, Hayashi et al. concluded that the presence of USP8 mutations may predict favorable responses to pasireotide, whereas non-mutated aggressive tumors might respond better to temozolomide because of their significantly weak expression of MGMT (108).

The clinical effectivity of medical treatment options preventing corticotroph tumor progression after BADX remains to be investigated in future studies.

\section{Recommendation 6}

There is no established medical therapy for CTP-BADX/ NS. In aggressive corticotroph tumors resistant to other treatment options, we suggest the use of temozolomide on an individual basis. 


\section{Supplementary materials}

This is linked to the online version of the paper at https://doi.org/10.1530/ EJE-20-1088.

\section{Declaration of interest}

$M$ Reincke has served on the advisory boards of Novartis and has received lecture fees and grants from Novartis, Ipsen, and Pfizer. I Bancos has served on the advisory boards of HRA Pharma and Corcept, and consulted for ClinCor. T Brue received consulting or speaker fees or grants from Novartis, Pfizer and Ipsen. He served as a board member or research investigator for Strongbridge, Pfizer, Ipsen and Recordati. O Chabre received speaker fees from Novartis, has been an investigator in a clinical study financed by Novartis and is part of a board of HRA Pharma and Recordati. A Elenkova reports serving as the principal investigator/subinvestigator of clinical trials for Corcept Therapeutics and Novartis and receiving consulting honoraria from Novartis. A Grossman has received lecture fees from Novartis, Ipsen, Pfizer and AAA. N Karavitaki has received educational grants from Novartis. A Lacroix received Clinical Trial Support from Novartis, GLWL Research Inc. and Corcept and served on advisory boards of Novartis, IPSEN and Pfizer. J Newell-Price has received research grants and consulting honoraria paid to the University of Sheffield from HRA Pharma, Novartis, Diurnal, and Ipsen. R Pivonello has been Principal Investigator of Research Studies for Novartis, HRA Pharma, Ipsen, Shire, Corcept Therapeutics, Cortendo AB; Co-investigator of Research Studies for Pfizer; received research grants from Novartis, Pfizer, Ipsen, HRA Pharma, Shire, IBSA; has been an occasional consultant for Novartis, Ipsen, Pfizer, Shire, HRA Pharma, Cortendo AB, Ferring and Italfarmaco; and has received fees and honoraria for presentations from Novartis and Shire. No conflict of interests that could be perceived as prejudicing the impartiality of this research reported. $K$ Ritzel has received lecture fee from Ipsen and served as investigator of clinical trials for Corcept. J Schopohl has received lecture fees from Novartis, Ipsen, and Pfizer. André Lacroix is an Associate Editor for European Journal of Endocrinology. He was not involved in the editorial or review process of this paper, on which he is listed as an author.

\section{Funding}

The workshop was supported by unrestricted grants of the Deutsche Forschungsgemeinschaft (10.000 €; DFG, German Research Foundation, project number 314061271-TRR 205 'The adrenal gland: Central relay in health and disease') of the Klinikum der Ludwig-Maximilians-Universität, and of the Carl Friedrich von Siemens Foundation, Munich. These funding sources had no role in the design of this study and did not have any role during its execution, analyses, interpretation of the data, or decision to submit results.

\section{Author contribution statement}

Martin Reincke: literature search, study design, data collection, analysis and interpretation (systematic review), writing. Adriana Albani: literature search, study design, data collection, analysis and interpretation (systematic review), writing. Guillaume Assie: data interpretation, writing. Irina Bancos: data interpretation, writing. Thierry Brue: data interpretation, writing. Michael Buchfelder: data interpretation, writing. Olivier Chabre: data interpretation, writing. Filippo Ceccato: data interpretation, writing. Andrea Daniele: data interpretation, writing. Mario Detomas: data interpretation, writing. Guido Di Dalmazi: data interpretation, writing. Atanaska Elenkova: data interpretation, writing. James Findling: data interpretation, writing. Ashley Grossman: data interpretation, writing. Celso E. Gomez-Sanchez: data interpretation, writing. Anthony P. Heaney: data interpretation, writing. Jürgen Honegger: data interpretation, writing. Niki Karavitaki: data interpretation, writing. Andre Lacroix: data interpretation, writing. Edward R. Laws: data interpretation, writing.
Marco Losa: data interpretation, writing. Masanori Murakami: data interpretation, writing. John D. Newell-Price: data interpretation, writing. Francesca Pecori Giraldi: data interpretation, writing. Luis G. Pérez-Rivas: data interpretation, writing. Rosario Pivonello: data interpretation, writing. William E. Rainey: data interpretation, writing. Silviu Sbiera: data interpretation, writing. Jochen Schopohl: data interpretation, writing. Constantine A. Stratakis: data interpretation, writing. Marily. Theodoropoulou: data interpretation, writing. Elisabeth F.C. van Rossum: data interpretation, writing. Elena Valassi: data interpretation, writing. Sabina Zacharieva: data. interpretation, writing. German Rubinstein: literature search, study design, data collection, analysis and interpretation (systematic review), writing. Katrin Ritzel: literature search, study design, data collection, analysis and interpretation (systematic review), writing. Martin Reincke, Adriana Albani, German Rubinstein and Katrin Ritzel contributed equally to this work.

\section{References}

1 Rubinstein G, Osswald A, Zopp S, Ritzel K, Theodoropoulou M, Beuschlein F \& Reincke M. Therapeutic options after surgical failure in Cushing's disease: a critical review. Best Practice and Research: Clinical Endocrinology and Metabolism 201933 101270. (https://doi. org/10.1016/j.beem.2019.04.004)

2 Albani A \& Theodoropoulou M. Persistent Cushing's disease after transsphenoidal surgery: challenges and solutions. Experimental and Clinical Endocrinology and Diabetes 2020 In press. (https://doi. org/10.1055/a-1220-6056)

3 Petersenn S, Beckers A, Ferone D, van der Lely A, Bollerslev J, Boscaro M, Brue T, Bruzzi P, Casanueva FF, Chanson P et al. Therapy of endocrine disease: outcomes in patients with Cushing's disease undergoing transsphenoidal surgery: systematic review assessing criteria used to define remission and recurrence. European Journal of Endocrinology 2015172 R227-R239. (https://doi.org/10.1530/EJE-140883)

4 Abu Dabrh AM, Singh Ospina NM, Al Nofal A, Farah WH, Barrionuevo P, Sarigianni M, Mohabbat AB, Benkhadra K, Carranza Leon BG, Gionfriddo MR et al. Predictors of biochemical remission and recurrence AFTER surgical and radiation treatments of Cushing disease: a systematic review and meta-analysis. Endocrine Practice 201622 466-475. (https://doi.org/10.4158/EP15922.RA)

5 Alexandraki KI, Kaltsas GA, Isidori AM, Storr HL, Afshar F, Sabin I, Akker SA, Chew SL, Drake WM, Monson JP et al. Long-term remission and recurrence rates in Cushing's disease: predictive factors in a single-centre study. European Journal of Endocrinology 2013168 639-648. (https://doi.org/10.1530/EJE-12-0921)

6 Braun LT, Rubinstein G, Zopp S, Vogel F, Schmid-Tannwald C, Escudero MP, Honegger J, Ladurner R \& Reincke M. Recurrence after pituitary surgery in adult Cushing's disease: a systematic review on diagnosis and treatment. Endocrine 202070 218-231. (https://doi. org/10.1007/s12020-020-02432-z)

7 Guyatt GH, Oxman AD, Vist GE, Kunz R, Falck-Ytter Y, AlonsoCoello P, Schunemann HJ \& GRADE Working Group. GRADE: an emerging consensus on rating quality of evidence and strength of recommendations. BMJ 2008336 924-926. (https://doi.org/10.1136/ bmj.39489.470347.AD)

8 Fraser R. Discussion on Cushing's syndrome. Proceedings of the Royal Society of Medicine $1957 \mathbf{5 0} 161-164$.

9 Nelson DH, Meakin JW, Dealy JB, Jr, Matson DD, Emerson K, Jr \& Thorn GW. ACTH-producing tumor of the pituitary gland. New England Journal of Medicine 1958259 161-164. (https://doi. org/10.1056/NEJM195807242590403)

10 Salassa RM, Kearns TP, Kernohan JW, Sprague RG \& Maccarty CS. Pituitary tumors in patients with Cushing's syndrome. Journal of Clinical Endocrinology and Metabolism 195919 1523-1539. (https:// doi.org/10.1210/jcem-19-12-1523) 
11 Assie G, Bahurel H, Coste J, Silvera S, Kujas M, Dugue MA, Karray F, Dousset B, Bertherat J, Legmann P et al. Corticotroph tumor progression after adrenalectomy in Cushing's disease: a reappraisal of Nelson's syndrome. Journal of Clinical Endocrinology and Metabolism 200792 172-179. (https://doi.org/10.1210/jc.2006-1328)

12 Mora B \& Bosch X. Medical eponyms: time for a name change. Archives of Internal Medicine 2010170 1499-1500. (https://doi. org/10.1001/archinternmed.2010.281)

13 Orth DN \& Liddle GW. Results of treatment in 108 patients with Cushing's syndrome. New England Journal of Medicine 1971285 243-247. (https://doi.org/10.1056/NEJM197107292850501)

14 Glenn F, Horwith M, Peterson RE \& Mannix H, Jr. Total adrenalectomy for Cushing's disease. Annals of Surgery 1972175 948-955. (https://doi.org/10.1097/00000658-197206010-00015)

15 Moore TJ, Dluhy RG, Williams GH \& Cain JP. Nelson's syndrome: frequency, prognosis, and effect of prior pituitary irradiation. Annals of Internal Medicine 1976 85 731-734. (https://doi.org/10.7326/00034819-85-6-731)

16 Hopwood NJ \& Kenny FM. Incidence of Nelson's syndrome after adrenalectomy for Cushing's disease in children: results of a nationwide survey. American Journal of Diseases of Children 1977131 1353-1356. (https://doi.org/10.1001/ archpedi.1977.02120250035005)

17 Cohen KL, Noth RH \& Pechinski T. Incidence of pituitary tumors following adrenalectomy. A long-term follow-up study of patients treated for Cushing's disease. Archives of Internal Medicine 1978138 575-579. (https://doi.org/10.1001/archinte.138.4.575)

18 McArthur RG, Hayles AB \& Salassa RM. Childhood Cushing disease: results of bilateral adrenalectomy. Journal of Pediatrics 197995 214-219. (https://doi.org/10.1016/s0022-3476(79)80654-x)

19 Sheeler LR, Grenfell RF, Jr, Schumacher OP \& Kumar MS. Nelson's syndrome; a new look. Cleveland Clinic Quarterly 198047 299-304. (https://doi.org/10.3949/ccjm.47.4.299)

20 Tomita A, Suzuki S, Hara I, Oiso Y, Mizuno S, Yogo H, Kuwayama A \& Kageyama N. Follow-up study on treatment in 27 patients with Cushing's disease: adrenalectomy, transsphenoidal adenomectomy and medical treatment. Endocrinologia Japonica 198128 197-205. (https://doi.org/10.1507/endocrj1954.28.197)

21 Barnett AH, Livesey JH, Friday K, Donald RA \& Espiner EA. Comparison of preoperative and postoperative ACTH concentrations after bilateral adrenalectomy in Cushing's disease. Clinical Endocrinology 198318 301-305. (https://doi. org/10.1111/j.1365-2265.1983.tb03215.x)

22 Kasperlik-Zaluska AA, Nielubowicz J, Wislawski J, Hartwig W, Zaluska J, Jeske W \& Migdalska B. Nelson's syndrome: incidence and prognosis. Clinical Endocrinology 198319 693-698. (https://doi. org/10.1111/j.1365-2265.1983.tb00046.x)

23 Kelly WF, MacFarlane IA, Longson D, Davies D \& Sutcliffe H. Cushing's disease treated by total adrenalectomy: long-term observations of 43 patients. Quarterly Journal of Medicine 198352 224-231.

24 Manolas KJ, Farmer HM, Wilson HK, Kennedy AL, Joplin GF, Montgomery DA, Kennedy TL \& Welbourn RB. The pituitary before and after adrenalectomy for Cushing's syndrome. World Journal of Surgery 19848 374-387. (https://doi.org/10.1007/BF01655082)

25 Thomas CG, Jr, Smith AT, Benson M \& Griffith J. Nelson's syndrome after Cushing's disease in childhood: a continuing problem. Surgery 198496 1067-1077.

26 Littley MD, Shalet SM, Beardwell CG, Ahmed SR \& Sutton ML. Long-term follow-up of low-dose external pituitary irradiation for Cushing's disease. Clinical Endocrinology 199033 445-455. (https:// doi.org/10.1111/j.1365-2265.1990.tb03883.x)

27 Grabner P, Hauer-Jensen M, Jervell J \& Flatmark A. Long-term results of treatment of Cushing's disease by adrenalectomy. European Journal of Surgery 1991157 461-464.

28 McCance DR, Russell CF, Kennedy TL, Hadden DR, Kennedy L \& Atkinson AB. Bilateral adrenalectomy: low mortality and morbidity in Cushing's disease. Clinical Endocrinology 199339 315-321. (https://doi.org/10.1111/j.1365-2265.1993.tb02371.x)

29 Kemink L, Pieters G, Hermus A, Smals A \& Kloppenborg P. Patient's age is a simple predictive factor for the development of Nelson's syndrome after total adrenalectomy for Cushing's disease. Journal of Clinical Endocrinology and Metabolism 199479 887-889. (https://doi. org/10.1210/jcem.79.3.8077377)

30 Misra D, Kapur MM \& Gupta DK. Incidence of Nelson's syndrome and residual adrenocortical function in patients of Cushing's disease after bilateral adrenalectomy. Journal of the Association of Physicians of India 199442 304-305.

31 O'Riordain DS, Farley DR, Young WF, Jr, Grant CS \& van Heerden JA. Long-term outcome of bilateral adrenalectomy in patients with Cushing's syndrome. Surgery 1994116 1088-1093; discussion 93-94.

32 Jenkins PJ, Trainer PJ, Plowman PN, Shand WS, Grossman AB, Wass JA \& Besser GM. The long-term outcome after adrenalectomy and prophylactic pituitary radiotherapy in adrenocorticotropindependent Cushing's syndrome. Journal of Clinical Endocrinology and Metabolism 199580 165-171. (https://doi.org/10.1210/ jcem.80.1.7829606)

33 Sonino N, Zielezny M, Fava GA, Fallo F \& Boscaro M. Risk factors and long-term outcome in pituitary-dependent Cushing's disease. Journal of Clinical Endocrinology and Metabolism 199681 2647-2652. (https:// doi.org/10.1210/jcem.81.7.8675592)

34 Pereira MA, Halpern A, Salgado LR, Mendonca BB, Nery M, Liberman B, Streeten DH \& Wajchenberg BL. A study of patients with Nelson's syndrome. Clinical Endocrinology 199849 533-539. (https:// doi.org/10.1046/j.1365-2265.1998.00578.x)

35 Imai T, Kikumori T, Funahashi H \& Nakao A. Surgical management of Cushing's syndrome. Biomedicine and Pharmacotherapy 2000 54 (Supplement 1) 140s-145s. (https://doi.org/10.1016/s07533322(00)80031-1)

36 Nagesser SK, van Seters AP, Kievit J, Hermans J, Krans HM \& van de Velde CJ. Long-term results of total adrenalectomy for Cushing's disease. World Journal of Surgery 200024 108-113. (https://doi. org/10.1007/s002689910020)

37 Kasperlik-Zaluska AA, Bonicki W, Jeske W, Janik J, Zgliczynski W \& Czernicki Z. Nelson's syndrome-46 years later: clinical experience with 37 patients. Zentralblatt für Neurochirurgie 200667 14-20. (https://doi.org/10.1055/s-2006-921430)

38 Gil-Cardenas A, Herrera MF, Diaz-Polanco A, Rios JM \& Pantoja JP. Nelson's syndrome after bilateral adrenalectomy for Cushing's disease. Surgery 2007141 147-151; discussion 51-52. (https://doi. org/10.1016/j.surg.2006.12.003)

39 Thompson SK, Hayman AV, Ludlam WH, Deveney CW, Loriaux DL \& Sheppard BC. Improved quality of life after bilateral laparoscopic adrenalectomy for Cushing's disease: a 10-year experience. Annals of Surgery 2007245 790-794. (https://doi.org/10.1097/01. sla.0000251578.03883.2f

40 Osswald A, Plomer E, Dimopoulou C, Milian M, Blaser R, Ritzel K, Mickisch A, Knerr F, Stanojevic M, Hallfeldt K et al. Favorable longterm outcomes of bilateral adrenalectomy in Cushing's disease. European Journal of Endocrinology 2014171 209-215. (https://doi. org/10.1530/EJE-14-0214)

41 Prajapati OP, Verma AK, Mishra A, Agarwal G, Agarwal A \& Mishra SK. Bilateral adrenalectomy for Cushing's syndrome: pros and cons. Indian Journal of Endocrinology and Metabolism 201519 834-840. (https://doi.org/10.4103/2230-8210.167544)

42 Graffeo CS, Perry A, Carlstrom LP, Meyer FB, Atkinson JLD, Erickson D, Nippoldt TB, Young WF, Jr, Pollock BE \& Van Gompel JJ. Characterizing and predicting the Nelson-Salassa syndrome. Journal of Neurosurgery 2017127 1277-1287. (https://doi.org/10.3171/2016.9 JNS161163)

43 Stratakis CA. "patients can have as many gene variants as they damn well please": why contemporary genetics presents us daily with a version of Hickam's dictum. Journal of Clinical Endocrinology and 
Metabolism 201297 E802-E804. (https://doi.org/10.1210/jc.20121650)

44 Rousseau E, Joubert M, Trzepla G, Parienti JJ, Freret T, Vanthygem MC, Desailloud R, Lefebvre H, Coquerel A, Reznik Y et al. Usefulness of time-point serum cortisol and ACTH measurements for the adjustment of glucocorticoid replacement in adrenal insufficiency. PLOS ONE 201510 e0135975. (https://doi.org/10.1371/ journal.pone.0135975)

45 Ben-Shlomo A \& Cooper O. Silent corticotroph adenomas. Pituitary 201821 183-193. (https://doi.org/10.1007/s11102-018-0864-8)

46 Pecori Giraldi F, Saccani A \& Cavagnini F. Endocrinology SGotH-PAAotISo. Assessment of ACTH assay variability: a multicenter study. European Journal of Endocrinology 2011164 505-512. (https://doi. org/10.1530/EJE-10-0962)

47 Greene LW, Geer EB, Page-Wilson G, Findling JW \& Raff H. Assayspecific spurious ACTH results lead to misdiagnosis, unnecessary testing, and surgical misadventure-A case series. Journal of the Endocrine Society 20193 763-772. (https://doi.org/10.1210/js.201900027)

48 Cohen AC, Goldney DC, Danilowicz K, Manavela M, Rossi MA, Gomez RM, Cross GE \& Bruno OD. Long-term outcome after bilateral adrenalectomy in Cushing's disease with focus on Nelson's syndrome. Archives of Endocrinology and Metabolism 201963 470-477. (https://doi.org/10.20945/2359-3997000000144)

49 Daniel E, Debono M, Caunt S, Girio-Fragkoulakis C, Walters SJ, Akker SA, Grossman AB, Trainer PJ \& Newell-Price J. A prospective longitudinal study of pasireotide in Nelson's syndrome. Pituitary 201821 247-255. (https://doi.org/10.1007/s11102-017-0853-3)

50 Jornayvaz FR, Assie G, Bienvenu-Perrard M, Coste J, Guignat L, Bertherat J, Silvera S, Bertagna X \& Legmann P. Pregnancy does not accelerate corticotroph tumor progression in Nelson's syndrome. Journal of Clinical Endocrinology and Metabolism 201196 E658-E662. (https://doi.org/10.1210/jc.2010-2235)

51 Machado AL, Nomikos P, Kiesewetter F, Fahlbusch R \& Buchfelder M. DNA-flow cytometry of 207 pituitary adenomas: ploidy, proliferation, and prognosis. Journal of Endocrinological Investigation 200528 795-801. (https://doi.org/10.1007/BF03347568)

52 Salehi F, Scheithauer BW, Moyes VJ, Drake WM, Syro LV, Manoranjan B, Sharma S, Horvath E \& Kovacs K. Low immunohistochemical expression of MGMT in ACTH secreting pituitary tumors of patients with Nelson syndrome. Endocrine Pathology 201021 227-229. (https://doi.org/10.1007/s12022-0109138-3)

53 Scheithauer BW, Gaffey TA, Lloyd RV, Sebo TJ, Kovacs KT, Horvath E, Yapicier O, Young WF, Jr, Meyer FB, Kuroki T et al. Pathobiology of pituitary adenomas and carcinomas. Neurosurgery $2006 \mathbf{5 9}$ 341-53; discussion 341; discussion. (https://doi.org/10.1227/01. NEU.0000223437.51435.6E)

54 Grossman AB. The molecular pathology of Cushing disease: are we nearly there? Journal of the Endocrine Society 20171 144-148. (https:// doi.org/10.1210/js.2017-00036)

55 Reincke M, Sbiera S, Hayakawa A, Theodoropoulou M, Osswald A, Beuschlein F, Meitinger T, Mizuno-Yamasaki E, Kawaguchi K, Saeki Y et al. Mutations in the deubiquitinase gene USP8 cause Cushing's disease. Nature Genetics 201547 31-38. (https://doi.org/10.1038/ ng.3166)

56 Perez-Rivas LG, Theodoropoulou M, Puar TH, Fazel J, Stieg MR, Ferrau F, Assie G, Gadelha MR, Deutschbein T, Fragoso MC et al. Somatic USP8 mutations are frequent events in corticotroph tumor progression causing Nelson's tumor. European Journal of Endocrinology 2018178 59-65. (https://doi.org/10.1530/EJE-17-0634)

57 Yordanova G, Martin L, Afshar F, Sabin I, Alusi G, Plowman NP, Riddoch F, Evanson J, Matson M, Grossman AB et al. Long-term outcomes of children treated for Cushing's disease: a single center experience. Pituitary 201619 612-624. (https://doi.org/10.1007/ s11102-016-0756-8)
58 Ludecke D, Kautzky R, Saeger W \& Schrader D. Selective removal of hypersecreting pituitary adenomas? An analysis of endocrine function, operative and microscopical findings in 101 cases. Acta Neurochirurgica 197635 27-42. (https://doi.org/10.1007/BF01405930)

59 Wilson CB, Tyrrell JB, Fitzgerald PA \& Pitts LH. Cushing's disease and Nelson's syndrome. Clinical Neurosurgery 198027 19-30. (https://doi. org/10.1093/neurosurgery/27.cn_suppl_1.19)

60 Ludecke DK, Breustedt HJ, Bramswig J, Kobberling J \& Saeger W. Evaluation of surgically treated Nelson's syndrome. Acta Neurochirurgica 198265 3-13. (https://doi.org/10.1007/BF01405437)

61 Kelly PA, Samandouras G, Grossman AB, Afshar F, Besser GM \& Jenkins PJ. Neurosurgical treatment of Nelson's syndrome. Journal of Clinical Endocrinology and Metabolism 200287 5465-5469. (https:// doi.org/10.1210/jc.2002-020299)

62 Kemink SA, Grotenhuis JA, De Vries J, Pieters GF, Hermus AR \& Smals AG. Management of Nelson's syndrome: observations in fifteen patients. Clinical Endocrinology 200154 45-52. (https://doi. org/10.1046/j.1365-2265.2001.01187.x)

63 Xing B, Ren Z, Su C, Wang R, Yang Y \& Hu Y. Microsurgical treatment of Nelson's syndrome. Chinese Medical Journal 2002115 1150-1152.

64 De Tommasi C, Vance ML, Okonkwo DO, Diallo A \& Laws ER, Jr. Surgical management of adrenocorticotropic hormone-secreting macroadenomas: outcome and challenges in patients with Cushing's disease or Nelson's syndrome. Journal of Neurosurgery 2005103 825-830. (https://doi.org/10.3171/jns.2005.103.5.0825)

65 Zielinski G, Witek P \& Maksymowicz M. Outcomes in pituitary surgery in Nelson's syndrome--therapeutic pitfalls. Endokrynologia Polska 201566 504-513. (https://doi.org/10.5603/EP.2015.0062)

66 Wislawski J, Kasperlik-Zaluska AA, Jeske W, Migdalska B, Janik J, Zaluska J \& Bonicki W. Results of neurosurgical treatment by a transsphenoidal approach in 10 patients with Nelson's syndrome. Journal of Neurosurgery 198562 68-71. (https://doi.org/10.3171/ jns.1985.62.1.0068)

67 Fukushima T. Trans-sphenoidal microsurgical treatment of Nelson's syndrome. Neurosurgical Review 19858 185-194. (https://doi. org/10.1007/BF01815443)

68 Knosp E, Steiner E, Kitz K \& Matula C. Pituitary adenomas with invasion of the cavernous sinus space: a magnetic resonance imaging classification compared with surgical findings. Neurosurgery 1993 33 610-617; discussion 7-8. (https://doi.org/10.1227/00006123199310000-00008)

69 Fountas A, Lim ES, Drake WM, Powlson AS, Gurnell M, Martin NM, Seejore K, Murray RD, MacFarlane J, Ahluwalia R et al. Outcomes of patients with Nelson's syndrome after primary treatment: a multicenter study from 13 UK Pituitary centers. Journal of Clinical Endocrinology and Metabolism 2020105 1527-1537. (https://doi. org/10.1210/clinem/dgz200)

70 Mehta GU, Sheehan JP \& Vance ML. Effect of stereotactic radiosurgery before bilateral adrenalectomy for Cushing's disease on the incidence of Nelson's syndrome. Journal of Neurosurgery 2013119 1493-1497. (https://doi.org/10.3171/2013.7.JNS13389)

71 Tran LM, Blount L, Horton D, Sadeghi A \& Parker RG. Radiation therapy of pituitary tumors: results in 95 cases. American Journal of Clinical Oncology 199114 25-29. (https://doi.org/10.1097/00000421199102000-00005)

72 Howlett TA, Plowman PN, Wass JA, Rees LH, Jones AE \& Besser GM. Megavoltage pituitary irradiation in the management of Cushing's disease and Nelson's syndrome: long-term follow-up. Clinical Endocrinology 198931 309-323. (https://doi. org/10.1111/j.1365-2265.1989.tb01255.x)

73 Grigsby PW, Stokes S, Marks JE \& Simpson JR. Prognostic factors and results of radiotherapy alone in the management of pituitary adenomas. International Journal of Radiation Oncology, Biology, Physics 198815 1103-1110. (https://doi.org/10.1016/03603016(88)90191-5) 
74 Pollock BE \& Young WF, Jr. Stereotactic radiosurgery for patients with ACTH-producing pituitary adenomas after prior adrenalectomy. International Journal of Radiation Oncology, Biology, Physics 200254 839-841. (https://doi.org/10.1016/s0360-3016(02)02975-9)

75 Mauermann WJ, Sheehan JP, Chernavvsky DR, Laws ER, Steiner L \& Vance ML. Gamma Knife surgery for adrenocorticotropic hormoneproducing pituitary adenomas after bilateral adrenalectomy. Journal of Neurosurgery 2007106 988-993. (https://doi.org/10.3171/ jns.2007.106.6.988)

76 Jane JA, Jr, Vance ML, Woodburn CJ \& Laws ER, Jr. Stereotactic radiosurgery for hypersecreting pituitary tumors: part of a multimodality approach. Neurosurgical Focus 200314 e12. (https:// doi.org/10.3171/foc.2003.14.5.13)

77 Caruso JP, Patibandla MR, Xu Z, Vance ML \& Sheehan JP. A longterm study of the treatment of Nelson's syndrome With gamma knife radiosurgery. Neurosurgery 201883 430-436. (https://doi. org/10.1093/neuros/nyx426)

78 Marek J, Jezkova J, Hana V, Krsek M, Liscak R, Vladyka V \& Pecen L. Gamma knife radiosurgery for Cushing's disease and Nelson's syndrome. Pituitary 201518 376-384. (https://doi.org/10.1007/ s11102-014-0584-7)

79 Vik-Mo EO, Oksnes M, Pedersen PH, Wentzel-Larsen T, Rodahl E, Thorsen F, Schreiner T, Aanderud S \& Lund-Johansen M. Gamma knife stereotactic radiosurgery of Nelson syndrome. European Journal of Endocrinology 2009160 143-148. (https://doi.org/10.1530/EJE-08-0687)

80 Cordeiro D, Xu Z, Li CE, Iorio-Morin C, Mathieu D, Sisterson ND, Kano H, Attuati L, Picozzi P, Sheehan KA et al. Gamma Knife radiosurgery for the treatment of Nelson's syndrome: a multicenter, international study. Journal of Neurological Surgery 2019133 336-342.

81 Petit JH, Biller BM, Yock TI, Swearingen B, Coen JJ, Chapman P, Ancukiewicz M, Bussiere M, Klibanski A \& Loeffler JS. Proton stereotactic radiotherapy for persistent adrenocorticotropinproducing adenomas. Journal of Clinical Endocrinology and Metabolism 200893 393-399. (https://doi.org/10.1210/jc.2007-1220)

82 Wattson DA, Tanguturi SK, Spiegel DY, Niemierko A, Biller BM, Nachtigall LB, Bussiere MR, Swearingen B, Chapman PH, Loeffler JS et al. Outcomes of proton therapy for patients with functional pituitary adenomas. International Journal of Radiation Oncology, Biology, Physics 201490 532-539. (https://doi.org/10.1016/j. ijrobp.2014.06.068)

83 Wilson PJ, Williams JR \& Smee RI. Nelson's syndrome: single centre experience using the linear accelerator (LINAC) for stereotactic radiosurgery and fractionated stereotactic radiotherapy. Journal of Clinical Neuroscience 201421 1520-1524. (https://doi.org/10.1016/j. jocn.2013.12.026)

84 Voges J, Kocher M, Runge M, Poggenborg J, Lehrke R, Lenartz D, Maarouf M, Gouni-Berthold I, Krone W, Muller RP et al. Linear accelerator radiosurgery for pituitary macroadenomas: a 7-year follow-up study. Cancer 2006107 1355-1364. (https://doi. org/10.1002/cncr.22128)

85 Lawrence JH, Tobias CA, Linfoot JA, Born JL \& Chong CY. Heavyparticle therapy in acromegaly and Cushing disease. JAMA 1976235 2307-2310.

86 Linfoot JA, Nakagawa JS, Wiedemann E, Lyman J, Chong C, Garcia J \& Lawrence JH. Heavy particle therapy: pituitary tumors. Bulletin of the Los Angeles Neurological Societies 197742 175-189.

87 Cassar J, Doyle FH, Lewis PD, Mashiter K, Noorden S \& Joplin GF. Treatment of Nelson's syndrome by pituitary implantation of yttrium-90 or gold-198. BMJ 19762 269-272. (https://doi. org/10.1136/bmj.2.6030.269)

88 Donnadieu M, Laurent MF, Luton JP, Bricaire H, Girard F \& Binoux M Synthetic MIF has no effect on beta-MSH and ACTH hypersecretion in Nelson's syndrome. Journal of Clinical Endocrinology and Metabolism 197642 1145-1148. (https://doi.org/10.1210/jcem-42-6-1145)

89 Mullan KR, Leslie H, McCance DR, Sheridan B \& Atkinson AB. The PPAR-gamma activator rosiglitazone fails to lower plasma ACTH levels in patients with Nelson's syndrome. Clinical Endocrinology 2006 64 519-522. (https://doi.org/10.1111/j.1365-2265.2006.02501.x)

90 Munir A, Song F, Ince P, Walters SJ, Ross R \& Newell-Price J. Ineffectiveness of rosiglitazone therapy in Nelson's syndrome. Journal of Clinical Endocrinology and Metabolism 200792 1758-1763. (https:// doi.org/10.1210/jc.2006-2005)

91 Kreutzer J, Jeske I, Hofmann B, Blumcke I, Fahlbusch R, Buchfelder M $\&$ Buslei R. No effect of the PPAR-gamma agonist rosiglitazone on ACTH or cortisol secretion in Nelson's syndrome and Cushing's disease in vitro and in vivo. Clinical Neuropathology 200928 430-439.

92 Krieger DT \& Luria M. Effectiveness of cyproheptadine in decreasing plasma ACTH concentrations in Nelson's syndrome. Journal of Clinical Endocrinology and Metabolism 197643 1179-1182. (https:// doi.org/10.1210/jcem-43-5-1179)

93 Cassar J, Mashiter K, Joplin GF, Rees LH \& Gilkes JJ. Cyproheptadine in Nelson's syndrome. Lancet 19762 426. (https://doi.org/10.1016/ s0140-6736(76)92451-x)

94 O'Mullane N, Walker B, Jefferson J, Hipkin L, Diver M \& Davis C. Lack of effect of bromocriptine on ACTH levels in patients with bilateral adrenalectomy for pituitary-dependent Cushing's syndrome. Journal of Endocrinological Investigation 19781 355-357. (https://doi. org/10.1007/BF03350982)

95 Mercado-Asis LB, Yanovski JA, Tracer HL, Chik CL \& Cutler GB. Acute effects of bromocriptine, cyproheptadine, and valproic acid on plasma adrenocorticotropin secretion in Nelson's syndrome. Journal of Clinical Endocrinology and Metabolism 199782 514-517. (https:// doi.org/10.1210/jcem.82.2.3742)

96 Shraga-Slutzky I, Shimon I \& Weinshtein R. Clinical and biochemical stabilization of Nelson's syndrome with long-term low-dose cabergoline treatment. Pituitary 20069 151-154. (https://doi. org/10.1007/s11102-006-9290-4)

97 Kasperlik-Zaluska AA, Zgliczynski W, Jeske W \& Zdunowski P. ACTH responses to somatostatin, valproic acid and dexamethasone in Nelson's syndrome. Neuro Endocrinology Letters 200526 709-712.

98 Kelly W, Adams JE, Laing I, Longson D \& Davies D. Longterm treatment of Nelson's syndrome with sodium valproate. Clinical Endocrinology 198828 195-204. (https://doi. org/10.1111/j.1365-2265.1988.tb03656.x)

99 Moyes VJ, Alusi G, Sabin HI, Evanson J, Berney DM, Kovacs K, Monson JP, Plowman PN \& Drake WM. Treatment of Nelson's syndrome with temozolomide. European Journal of Endocrinology 2009 160 115-119. (https://doi.org/10.1530/EJE-08-0557)

100 Kurowska M, Nowakowski A, Zielinski G, Malicka J, Tarach JS, Maksymowicz M \& Denew P. Temozolomide-induced shrinkage of invasive pituitary adenoma in patient with Nelson's syndrome: a case report and review of the literature. Case Reports in Endocrinology 2015 2015 623092. (https://doi.org/10.1155/2015/623092)

101 Losa M, Mazza E, Terreni MR, McCormack A, Gill AJ, Motta M, Cangi MG, Talarico A, Mortini P \& Reni M. Salvage therapy with temozolomide in patients with aggressive or metastatic pituitary adenomas: experience in six cases. European Journal of Endocrinology 2010163 843-851. (https://doi.org/10.1530/EJE-10-0629)

102 Bruno OD, Juarez-Allen L, Christiansen SB, Manavela M, Danilowicz K, Vigovich C \& Gomez RM. Temozolomide therapy for aggressive pituitary tumors: results in a small series of patients from Argentina. International Journal of Endocrinology 20152015587893. (https://doi.org/10.1155/2015/587893)

103 Kelestimur F, Utas C, Ozbakir O, Selcuklu A, Kandemir O \& Ozcan N. The effects of octreotide in a patient with Nelson's syndrome. Postgraduate Medical Journal 199672 53-54. (https://doi.org/10.1136/ pgmj.72.843.53)

104 Petrini L, Gasperi M, Pilosu R, Marcello A \& Martino E. Long-term treatment of Nelson's syndrome by octreotide: a case report. Journal of Endocrinological Investigation 199417 135-139. (https://doi. org/10.1007/BF03347703) 
105 Lamberts SW, Uitterlinden P \& Klijn JM. The effect of the long-acting somatostatin analogue SMS 201-995 on ACTH secretion in Nelson's syndrome and Cushing's disease. Acta Endocrinologica 1989120 760-766. (https://doi.org/10.1530/acta.0.1200760)

106 Raverot G, Burman P, McCormack A, Heaney A, Petersenn S, Popovic V, Trouillas J, Dekkers OM \& European Society of E. European Society of Endocrinology Clinical Practice Guidelines for the management of aggressive pituitary tumours and carcinomas. European Journal of Endocrinology 2018178 G1-G24. (https://doi. org/10.1530/eje-17-0796)
107 Lacroix A, Gu F, Schopohl J, Kandra A, Pedroncelli AM, Jin L \& Pivonello R. Pasireotide treatment significantly reduces tumor volume in patients with Cushing's disease: results from a Phase 3 study. Pituitary 202023 203-211. (https://doi.org/10.1007/s11102019-01021-2)

108 Hayashi K, Inoshita N, Kawaguchi K, Ibrahim Ardisasmita A, Suzuki H, Fukuhara N, Okada M, Nishioka H, Takeuchi Y, Komada M et al. The USP8 mutational status may predict drug susceptibility in corticotroph adenomas of Cushing's disease. European Journal of Endocrinology 2016 174 213-226. (https://doi.org/10.1530/eje-15-0689)

Received 21 September 2020

Revised version received 23 November 2020

Accepted 12 January 2021 